\title{
AKTIVITAS FISIK PASIEN HIPERTENSI
}

\author{
Neng Yulia Maudi ${ }^{1}$, Hesti Platini' ${ }^{2}$, Sandra Pebrianti ${ }^{3}$ \\ ${ }^{1,2,3}$ Fakultas Keperawatan, Universitas Padjadjaran \\ hesti.platini@gmail.com
}

\begin{abstract}
ABSTRAK
Aktivitas fisik termasuk manajemen nonfarmakologi yang dapat memengaruhi tekanan darah. Kurang aktivitas fisik menyebabkan tekanan darah selalu tinggi melebihi rentang nilai normal 130/90 mmHg, jika dalam waktu lama akan berisiko komplikasi. Tekanan darah penderita hipertensi minimal dapat dikendalikan dengan melakukan aktivitas fisik sehingga dapat mencegah komplikasi. Penelitian ini bertujuan untuk mengetahui bagaimana gambaran aktivitas fisik pasien hipertensi.Penelitian ini merupakan penelitian deskriptif kuantitatif. Sampel sebanyak 99 penderita hipertensi tanpa komplikasi, ditetapkan dengan cara purposive sampling. Pengumpulan data dilakukan dengan menggunakan kuesioner International Physical Activity Questionnaire (IPAC) yang merupakan kuesioner baku dengan 27 pertanyaan dan nilai uji validitas $r$ hitung $(0,444)$ $>$ r tabel $(0,361)$ serta Cronbach alpha 0,713 menyatakan reabilitas. Hasil penelitian dianalisis menggunakan analisa univariat, disajikan dalam bentuk tabel distribusi frekuensi. Hasil penelitian menunjukkan sebagian besar responden melakukan aktivitas fisik sedang dengan presentase $(62,6 \%)$. Responden yang termasuk aktivitas fisik berat $(28,3 \%)$, dan sebagian kecil termasuk aktivitas fisik ringan $(9,1 \%)$. Aktivitas fisik berada pada kategori sedang dan berat tetapi masih ada sebagian kecil yang termasuk aktivitas fisik ringan. Hal ini perlu dilakukan pembinaan lebih lanjut oleh pihak puskesmas seperti meningkatkan Program Posbindu melalui penyuluhan, pelaksanaan aktivitas fisik khusus penderita hipertensi.
\end{abstract}

Kata kunci : aktivitas fisik, hipertensi, terapi nonfarmakologi

\section{PHYSICAL ACTIVITY OF HYPERTENSIVE PATIENTS}

\section{ABSTRACT}

Physical activity includes non-pharmacological management that can affect blood pressure. Lack of physical activity causes blood pressure always to be high, exceeding the normal range of 130/90 $\mathrm{mmHg}$, if for a long time there will be a risk of complications. People with hypertension can control their blood pressure at least by doing physical activity to prevent complications. This study aims to determine how the description of the physical activity of hypertensive patients. This research is quantitative descriptive with 99 hypertensive patients sample without complications determined by purposive sampling. Data was collected using the International Physical Activity Questionnaire, which is a standard questionnaire with 27 questions and the validity test value of $r$ count $(0,444)>r$ table $(0,361)$ and Cronbach alpha 0,713 states reliability. The results were analyzed using univariate analysis, presented in the form of a frequency distribution table. The results showed that most respondents did a moderate physical activity with a percentage (62,6\%). Respondents including heavy physical activity $(28,3 \%)$, and a small proportion included light physical activity (9,1\%). Thus, physical activity is moderate and strenuous, but there is still a small proportion that includes light physical activity. It requires further guidance by the Public health center, such as increasing the posbindu 
program through counseling and implementing special physical activities for people with hypertension.

Keyword: hypertension, non-pharmacological therapy, physical activity

\section{PENDAHULUAN}

Hipertensi adalah penyakit yang tidak menular sering dikenal dengan tekanan darah tinggi dengan kondisi pembuluh darah mengalami peningkatan secara persisten di atas normal 130/90 mmHg (AHA, 2017). Berdasarkan data Kementrian kesehatan pada tahun 2018 hipertensi menjadi penyakit tidak menular peringkat pertama yang didiagnosis di berbagai fasilitas kesehatan hingga mencapai 185.857 kasus. Hipertensi sering terjadi di negara yang telah berkembang termasuk Indonesia (Manuntung, 2018).

Prevalensi hipertensi di Indonesia cukup tinggi, menurut data Kementrian Kesehatan tahun 2018 di Indonesia terjadi peningkatan jumlah penderita darah tinggi pada tahun 2013 sebanyak 26,5\% meningkat di tahun 2018 sebanyak 34,1\% (Kementerian Kesehatan RI, 2018). Pada tahun 2016, prevalensi penderita hipertensi di Jawa Barat juga cukup tinggi mencapai 2,46\% dengan banyak kasus hipertensi yang telah diperiksa sebanyak 8.029.245 penderita, kasus hipertensi tersebut tersebar pada 26 Kabupaten/ kota termasuk salah satunya Kabupaten Garut sebanyak 3,24\% (Dinas Kesehatan Provinsi Jawa Barat, 2017). Prevalensi penderita hipertensi di seluruh puskesmas Kabupaten Garut mencakup kelompok umur $\geq 18$ tahun sebanyak 118.917 penderita (Profil Kesehatan Kab.Garut, 2017). Hal tersebut menunjukkan tingginya prevalensi penyakit hipertensi.

Peningkatan tekanan darah secara terus- menerus berlangsung lama dan tidak dikendalikan atau ditangani sejak dini bersiko menyebabkan dampak lebih berat dari hipertensi seperti: penyakit jantung koroner, terjadinya strok karena adanya penyumbatan pada pembuluh darah, dan gagal ginjal (Yulanda, Lisiswanti, 2017). Perawatan untuk mengontrol tekanan darah penderita hipertensi pada dasarnya dapat dilaksanakan dengan cara farmakologis serta nonfarmakologis.

Penatalaksaan hipertensi secara farmakologis lebih efektif dalam menurunkan tekanan darah apabila diimbangi dengan penatalaksanaan nonfarmakologis (Hidayat, 2010). Penatalaksanaan yang termasuk kedalam terapi nonfarmakologi yakni dengan cara modifikasi gaya hidup diantaranya diet hipertensi, melakukan aktivitas fisik, manajemen stres, kepatuhan penderita mengontrol tekanan darah secara teratur (Setyowati \& Wahyuni, 2019). Manurung \& Wibowo (2016) menyatakan penatalaksanaan terapi nonfarmakologi dengan modifikasi gaya hidup harus dilaksanakan oleh penderita hipertensi sebelum menggunakan terapi farmakologi atau sebelum mengonsumsi obat-obatan.

Mordiana, Weta (2014) yang meneliti tentang gaya hidup menyatakan hasil penderita hipertensi mematuhi minum obat sebesar $87,8 \%$, patuh terhadap diet sebesar $68,8 \%$, dan yang aktif beraktivitas fisik olahraga sebesar 53,7\%. Didukung oleh penelitian Fadilah (2017) menyatakan hasil gaya hidup penderita hipertensi kategori pola makan dalam kategori baik sebesar $82,9 \%$, pola istirahat dalam kategori baik $64,3 \%$, pola merokok baik $94,3 \%$, sedangkan didapatkan pola aktivitas fisik yang buruk sebesar 51,4\%. Dapat disimpulkan manajemen nonfarmakologi yang masih belum terselenggara dengan baik yaitu aktivitas fisik.

Aktivitas fisik dapat dilakukan dengan memperhatikan beberapa hal yakni terkait durasi, frekuensi, serta intensitas aktivitas fisik. 
Adapun intensitas merupakan takaran keras atau ringan suatu aktivitas atau latihan yang dilakukan (Andriyati, Hendarsih, 2011). JNC 7 (The Seventh Report of The Join National) menganjurkan tingkat aktivitas fisik sebagai modifikasi gaya hidup pada penderita hipertensi yakni aktivitas fisik yang dilakukan secara teratur dengan intensitas sedang. Hal ini diketahui akan membantu mengurangi tekanan darah sebesar 4-9 mmHg, aktivitas fisik intensitas sedang tersebut setara dengan durasi aktivitas fisik 30-60 menit/hari atau minimalnya dalam 3 hari/minggu (Muhadi, 2016). World Health Organization (WHO, 2009) menyatakan aktivitas fisik dilakukan cukup dengan aktivitas fisik yang rutin dan dilakukan secara teratur minimal dalam 30 menit dengan aktivitas fisik sedang atau setidaknya dalam 20 menit selama 5 hari/ minggu. Jenis aktivitas fisik yang secara spesifik untuk penderita hipertensi yakni aktivitas rutin dan terkontrol (Herdianto, 2014).

Turege, Kinasih, \& Dyah (2019) menyatakan bahwa manusia seringkali merasa malas melakukan aktivitas fisik karena dipengaruhi oleh kemajuan teknologi ke arah modern pada saat ini sehingga merasa telah dipermudahkan oleh berbagai fasilitas modern yang sudah tersedia dan dampaknya berpengaruh juga terhadap gaya hidup manusia. Kurangnya aktivitas fisik sangat berdampak buruk baik bagi kesehatan dan kualitas hidup manusia.

Alves et al., (2016) menyatakan ketidakaktifan melakukan aktivitas fisik adalah faktor risiko utama keempat untuk penyakit tidak menular, bertanggung jawab $12,2 \%$ dari beban global infarktus miokardia akut, 6\% kematian, meningkatkan risiko diabetes, penumpukan lemak visceral, kolestrol darah tinggi, disertai dengan peradangan pembuluh darah derajat rendah yang berhubungan dengan resistensi insulin dan aterosklorosis yang mengarah pada perkembangan penyakit arteri koroner. Dampak kurang aktivitas fisik akan meningkatkan risiko kelebihan pada berat badan atau obesitas dan risiko terjadinya hipertensi atau kekambuhan (Aryzki, Ayuchecaria, \& Sari, 2019).

Kurang aktivitas fisik pada penderita hipertensi dapat menyebabkan selalu tinggi tekanan darah, jika dalam rentang waktu yang lama dapat berisiko mengakibatkan rusaknya sel saraf sehingga terjadinya kelumpuhan pada organ karena adanya pecah pembuluh darah otak (Arlianti, Muhaimin, \& Anwar, 2019). Dampak lain kurangnya aktivitas fisik/tidak adanya aktivitas fisik pada penderita hipertensi akan berisiko mengalami komplikasi berbagai penyakit kronis (strok, gagal jantung, gagal ginjal) (Afiah, Yusran, \& Sety, 2018). Selain itu menurut penelitian Vestabilivy \& Rukayah (2014) menyatakan terdapat hubungan yang sangat signifikan antara kualitas hidup dengan aktivitas fisik secara teratur, pada penelitian menjelaskan bahwa orang dengan hipertensi yang kurang aktivitas fisik diketahui berisiko 5,236 kali memiliki tingkat kualitas hidup kurang baik dibandingkan dengan penderita yang melakukan aktivitas fisik secara teratur.

Berdasarkan data Profil Kesehatan Kabupaten Garut (2017) menunjukkan bahwa dari seluruh puskesmas di Kabupaten Garut, Puskesmas Guntur termasuk salah satu Puskesmas yang masuk dalam urutan tertinggi ke- 12 dengan jumlah penderita hipertensi sebanyak 763 lakilaki dan 1722 penderita perempuan dengan jumlah total penderita hipertensi sebanyak 2485 penderita. Data tersebut menunjukkan tingginya angka penderita hipertensi di wilayah kerja Puskesmas Guntur Garut. Puskesmas merupakan pusat pelayanan kesehatan masyarakat yang menduduki tingkat pertama dan memiliki peranan penting dalam membantu pembangunan kesehatan nasional (Kemenkes RI, 2014).

Berdasarkan kajian literatur di atas mengenai pentingnya aktivitas fisik untuk 
pengelolaan dan pencegahan tekanan darah tinggi, untuk itu peneliti tertarik melakukan penelitian dengan judul Gambaran Aktivitas Fisik Pasien Hipertensi di Wilayah Kerja Puskesmas Guntur Garut.

\section{METODOLOGI}

Rancangan penelitian menggunakan deskriptif kuantitatif. Variabel utama penelitian ini adalah aktivitas fisik pasien hipertensi. Populasi pada penelitian ini adalah pasien hipertensi di Wilayah Kerja Puskesmas Guntur berdasarkan Profil Kesehatan Kabupaten Garut (2017) sebanyak 2485 pasien. Pengambilan sampel pada penelitian ini ditentukan dengan rumus slovin sehingga didapatkan jumlah sampel yang diteliti sebanyak 99 responden. Teknik sampling menggunakan teknik purposive sampling dengan kriteria inklusi yakni pasien hipertensi tanpa komplikasi atau tanpa penyakit penyerta, pasien dengan nilai tekanan darah 130$150 \mathrm{mmHg}$, pasien dewasa produktif dengan rentang usia 18-59 tahun, serta pasien sadar atau tidak mengalami penurunan kesadaran, sedangkan kriteria eksklusi yakni pasien dengan komplikasi atau dengan penyakit penyerta, pasien lanjut usia di atas 60 tahun, responden tidak ada di tempat selama penelitian. Setelah pemilahan menggunakan kriteria inklusi dan eksklusi responden yang diteliti tetap 99 responden.

Penelitian ini dilakukan di Posbindu wilayah kerja Puskesmas Guntur Garut dan pengumpulan data dilakukan selama kurun waktu kurang lebih 1 bulan dengan cara pengukuran tekanan darah terlebih dahulu disertai kunjungan rumah. Penelitian ini telah lolos uji etik dengan nomor: 534/UN6.KEP/EC/2020.

Instrumen yang digunakan yaitu International Physical Activity Questionnaire (IPAQ) merupakan kuesioner yang dikembangkan oleh WHO terdiri dari 5 domain lengkap aktivitas fisik dan didalamnya ada 27 pertanyaan. Pada penelitian ini Instrumen IPAQ diambil dari Booth ML (n: 1880) dan telah diujikan oleh Nor'alia et., al (2017) dengan nilai uji validitas $r$ hitung $(0,444)>\mathrm{r}$ tabel $(0,361)$ dengan Cronbach alpha 0,713 yang menyatakan hasil reabilitas. Analisis data yang digunakan yaitu univariat yang disajikan dalam bentuk distribusi frekuensi.

\section{HASIL}

Penelitian dilaksanakan kepada pasien hipertensi dewasa usia produktif di Wilayah Kerja Puskesmas Guntur Garut dengan kurun waktu kurang lebih 1 bulan. Pengambilan data dilakukan kepada 99 responden dalam kegiatan Posbindu dan disertai dengan pengukuran tekanan darah terlebih dahulu. Hasil dari penelitian ini disajikan dalam bentuk tabel yang menggambarkan data demografi dan aktivitas fisik pasien hipertensi.

Karakteristik pada penelitian ini terdiri atas data demografi pasien hipertensi yang termasuk didalamnya antara lain usia, status, jenis kelamin, pendidikan, dan pekerjaan.

Data dari masing-masing karakteristik demografi terdapat pada tabel berikut :

Tabel 1. Distribusi Frekuensi Data Demografi Berdasarkan Karakteristik Pasien Hipertensi

\begin{tabular}{lcc} 
& $(\mathrm{n}=99)$ & \\
\hline $\begin{array}{l}\text { Karakteristik } \\
\text { Responden }\end{array}$ & $\mathbf{f}$ & $\%$ \\
\hline Usia & & \\
18-24 Tahun & 36 & 36,4 \\
25-44 Tahun & 62 & 62,6 \\
45-59 Tahun & & \\
Jenis Kelamin & 7 & 7,1 \\
Laki-Laki & 92 & 92,9 \\
Perempuan & & \\
Status & 89 & 89,9 \\
Menikah & 10 & 10,1 \\
Cerai &
\end{tabular}




\begin{tabular}{lcc}
\hline $\begin{array}{l}\text { Karakteristik } \\
\text { Responden }\end{array}$ & f & \% \\
\hline Pendidikan & & \\
Tidak Sekolah & 1 & 1,0 \\
SD & 44 & 44,4 \\
SMP & 30 & 30,3 \\
SMA & 23 & 23,2 \\
Perguruan Tinggi & 1 & 1,0 \\
Pekerjaan & & \\
Tidak Bekerja & 3 & 3,0 \\
Wiraswasta & 21 & 21,2 \\
PNS & 1 & 1,0 \\
Ibu Rumah tangga & 74 & 74,7 \\
\hline
\end{tabular}

Berdasarkan tabel 1 diperoleh data berdasarkan karakteristik demografi sebagian besar responden terdiri dari usia 45-59 tahun sebanyak 62 responden $(62,6 \%)$ dan paling sedikit usia 18-24 tahun sebanyak 1 responden (1,0\%). Responden dengan jenis kelamin perempuan lebih banyak sejumlah 92 orang $(92,9 \%)$ dibandingkan dengan responden laki-laki. Hampir seluruhnya responden sudah menikah yakni 89 orang (89,9\%). Pendidikan sebagian besar responden yakni SD sebanyak 44 orang $(44,4 \%)$, dan hampir seluruhnya responden merupakan ibu rumah tangga sebanyak 74 orang $(74,4 \%)$.

Tabel 2. Hasil Aktivitas Fisik Pasien Hipertensi di Wilayah Kerja Puskesmas Guntur Garut.

\begin{tabular}{|c|c|c|}
\hline Tingkat Aktivitas Fisik & $\mathbf{f}$ & $\%$ \\
\hline Ringan & 9 & 9,1 \\
\hline Sedang & 62 & 62,6 \\
\hline Berat & 28 & 28,3 \\
\hline Jumlah & 99 & 100 \\
\hline \multicolumn{3}{|c|}{$\begin{array}{l}\text { Berdasarkan tabel } 2 \text { didapatkan hasil } \\
\text { va sebagian besar responden termasuk ke } \\
\text { m tingkat aktivitas fisik sedang sebanyak } \\
\text { responden }(62,6 \%) \text {, sebagian responden } \\
\text { lasuk ke dalam aktivitas fisik berat sebanyak } \\
\text { responden }(28,3 \%) \text {, dan sebagian kecil } \\
\text { onden termasuk ke dalam aktivitas fisik } \\
\text { an yakni sebanyak } 9 \text { responden }(9,1 \%) \text {. }\end{array}$} \\
\hline
\end{tabular}

Tabel 3. Distribusi Frekuensi Gambaran Aktivitas Fisik Pasien Hipertensi di Wilayah Kerja Puskesmas Guntur Garut (n=99)

\begin{tabular}{lcccccc}
\hline \multirow{2}{*}{ Karakteristik Responden } & \multicolumn{2}{c}{ Ringan } & \multicolumn{2}{c}{ Sedang } & \multicolumn{2}{c}{ Berat } \\
\cline { 2 - 7 } Usia & f & \% & f & \% & f & $\%$ \\
$18-24$ & 0 & 0,0 & 1 & 1,6 & 0 & 0,0 \\
$25-44$ & 6 & 66,7 & 17 & 27,4 & 13 & 46,4 \\
$45-59$ & 3 & 33,3 & 44 & 71,1 & 15 & 53,6 \\
Jenis Kelamin & & & & & & \\
Laki-Laki & 1 & 11,1 & 5 & 8,1 & 1 & 3,6 \\
Perempuan & 8 & 88,9 & 57 & 91,9 & 27 & 96,4 \\
Status & & & & & & \\
Menikah & 8 & 88,9 & 56 & 90,3 & 25 & 89,3 \\
Cerai & 1 & 11,1 & 6 & 9,7 & 3 & 10,7 \\
Pendidikan & & & & & & \\
Tidak Sekolah & & & & & & \\
SD & 0 & 0,0 & 1 & 1,6 & 0 & 0,0 \\
SMP & 4 & 44,4 & 23 & 37,1 & 17 & 60,7 \\
SMA & 3 & 33,3 & 20 & 32,3 & 7 & 25,0 \\
Perguruan tinggi & 2 & 22,2 & 17 & 27,4 & 4 & 14,3 \\
\hline
\end{tabular}




\begin{tabular}{lcccccc}
\hline \multirow{2}{*}{ Karakteristik Responden } & \multicolumn{2}{c}{ Ringan } & \multicolumn{2}{c}{ Sedang } & \multicolumn{2}{c}{ Berat } \\
\cline { 2 - 7 } \multicolumn{1}{c}{ Pekerjaan } & f & $\mathbf{\%}$ & $\mathbf{f}$ & $\mathbf{\%}$ & $\mathbf{f}$ & $\mathbf{\%}$ \\
Tidak Bekerja & 1 & 11,1 & 1 & 1,6 & 1 & 3,6 \\
Wiraswasta & 1 & 11,1 & 10 & 16,1 & 10 & 35,7 \\
PNS & 0 & 0,0 & 1 & 1,6 & 0 & 0,0 \\
Ibu Rumah Tangga & 7 & 77,8 & 50 & 80,6 & 17 & 60,7 \\
\hline
\end{tabular}

Berdasarkan tabel 3 didapatkan hasil bahwa sebagian besar responden dengan rentang usia 45-59 tahun melakukan aktivitas fisik sedang sebanyak (71,1\%), hampir seluruhnya responden berjenis kelamin perempuan melakukan aktivitas fisik berat $(96,4 \%)$, responden yang sudah menikah hampir seluruhnya melakukan aktivitas fisik sedang (90,3\%), sebagian besar responden dengan status pendidikan SD melakukan aktivitas fisik berat sebanyak (60,7\%), dan sebagian besar responden yang termasuk ibu rumah tangga melakukan aktivitas fisik sedang sebanyak $(80,6 \%)$.

\section{PEMBAHASAN}

Berdasarkan tabel 3 menunjukkan hasil bahwa tingkat aktivitas fisik penderita hipertensi di Wilayah Kerja Puskesmas Guntur Garut sebagian besar termasuk ke dalam aktivitas fisik sedang dengan persentase $(62,6 \%)$. Hampir setengahnya termasuk ke dalam aktivitas fisik berat dengan persentase $(28,3 \%)$, dan sebagian kecil termasuk ke dalam aktivitas fisik ringan dengan persentase $(9,1 \%)$. Responden dengan aktivitas fisik sedang lebih mendominasi pada penelitian ini karena didapatkan data hasil penelitian bahwa aktivitas fisik sedang hampir seluruhnya dilakukan oleh responden yang sudah menikah sebanyak (90,3\%), dan hampir seluruhnya aktivitas fisik sedang dilakukan oleh responden yang merupakan ibu rumah tangga sebanyak $(80,6 \%)$.

Berdasarkan hasil penelitian tersebut peneliti menemukan sebagian besar responden yang termasuk ke dalam aktivitas fisik sedang karena dipengaruhi oleh sebagian besar responden yang merupakan ibu rumah tangga sehingga aktivitas yang dilakukan berupa aktivitas mencuci, membersihkan rumah seperti mengepel, menyapu, membersihkan halaman, menonton televisi, aktivitas transportasi, dan aktivitas ibu rumah tangga lainnya. Hal ini juga dipengaruhi oleh situasi pandemi Covid-19 saat ini sehingga sebagian besar responden mengatakan lebih membatasi untuk beraktivitas di luar rumah. Akan tetapi, ada beberapa responden yang menyempatkan untuk melakukan aktivitas fisik seperti berjalan selama minimalnya 10 menit lebih dalam sehari atau dalam seminggu 1 kali diwaktu santai, atau olahraga sederhana di luar rumah.

Aktivitas fisik sedang pada penelitian ini juga lebih banyak dilakukan oleh responden dengan rentang usia 45-59 tahun sebanyak (71,1\%). Akan tetapi didalam penelitian Riskawati, Prabowo, Rasyid (2018) menyatakan bahwa pada faktor usia tidak memiliki hubungan yang bermakna atau yang signifikan dengan tingkat aktivitas fisik yang dilakukan oleh seseorang, karena tingkat aktivitas sangat bergantung pada pola kebiasaan aktivitas yang sudah tertanam atau menjadi kebiasaan sebelumnya.

Penelitian ini sejalan dengan penelitian terdahulu yang dilakukan oleh Karim, Onibala, Kallo (2018) yang menyatakan hasil responden lebih banyak melakukan aktivitas fisik sedang. Penelitian ini juga menuturkan bahwa sebanyak 
$70 \%$ responden yang melakukan aktivitas fisik sedang karena aktivitas fisik yang dilakukan yakni aktivitas mencuci pakaian, menyetrika, mencuci piring menyapu serta memasak. Penelitian ini juga sejalan dengan penelitian Aryzki, Ayuchecaria, Khumaira (2019) menyatakan hasil pada domain aktivitas fisik responden sebagian besar responden termasuk ke dalam aktivitas fisik sedang sebanyak 25 orang, aktivitas fisik ringan sebanyak 2 orang, dan aktivitas fisik berat sebanyak 3 orang.

Mukti (2020) menyatakan bahwa aktivitas fisik intensitas sedang dapat menurunkan tekanan darah sebanyak 4-9 mmHg pada tekanan sistolik jika dilakukan secara teratur dengan durasi 30-60 menit/hari minimalnya 3 hari dalam seminggu. Didukung oleh penelitian Platini, Pebrianti, Maulana (2019) menyatakan bahwa aktivitas intensitas sedang mampu menurunkan tekanan darah seperti salah satunya dengan senam tera, pada penelitiannya menunjukkan hasil bahwa senam tera dapat menghasilkan efek penurunan terhadap tekanan darah dan ada hubungan yang kuat dari frekuensi senam tera terhadap tekanan darah sistolik. Penelitian Listiyaningsih, Siswati, Kurdanti (2014) menyatakan hasil di dalam penelitiannya bahwa ada hubungan bermakna antara aktivitas fisik dengan tekanan darah. Penelitian ini menyatakan responden dengan aktivitas fisik kurang berisiko 4,9 kali hipertensi dibandingkan dengan responden yang beraktivitas fisik sedang, penelitian ini juga menunjukkan bahwa aktivitas fisik sedang dan berat dapat mencegah kejadian strok.

Berdasarkan hasil penelitian sebanyak 28,3\% termasuk ke dalam aktivitas fisik berat. Hampir seluruhnya aktivitas fisik berat dilakukan oleh responden berjenis kelamin perempuan sebanyak (96,4\%). Hal ini karena dipengaruhioleh banyaknya responden perempuan dibandingkan dengan laki-laki. Physical Activity Guidelines (2017) menyatakan aktivitas berat merupakan aktivitas yang menyebabkan napas menjadi lebih cepat dan lebih banyak mengeluarkan energi. Aktivitas fisik berat tersebut setara dengan aerobik, bersepeda dengan cepat, menimba air, dan mengangkat beban berat. Berdasarkan hasil wawancara pada penelitian ini sebagian responden melakukan aktivitas fisik berat seperti aerobik dalam seminggu 1 kali, ada pula seminggu 2 kali selama kurang lebih 30-60 menit dalam sekali waktu. Aktivitas fisik tersebut sudah menjadi rutinitas responden setiap minggu. Aktivitas aerobik diketahui mampu menurunkan tekanan darah, didukung oleh penelitian Indrawati (2018) yang menyatakan hasil ada pengaruh senam aerobik terhadap penurunan tekanan darah penderita hipertensi dengan nilai ( $p$ value $=0,000$ ; $a=0,05)$. Penelitian ini menyatakan bahwa pemberian senam aerobik efektif menurunkan tekanan darah pada penderita hipertensi.

Responden pada penelitian ini lebih mendominasi aktivitas fisik sedang dan berat, akan tetapi masih ada sebagian kecil responden yang termasuk ke dalam aktivitas fisik ringan sebanyak 9,1\%. Afiah, Yusran, Sety (2018) dalam penelitiannya menyatakan semakin ringan aktivitas fisik yang dilakukan seseorang maka akan semakin meningkatkan risiko untuk terjadinya hipertensi, semakin aktif seseorang dalam melakukan aktivitas fisik maka akan semakin normal tekanan darahnya. Sebaliknya jika seseorang tidak aktif atau kurang dalam melakukan aktivitas fisik maka akan semakin tinggi juga nilai tekanan darahnya. Aktivitas fisik ringan juga dapat mengontrol tekanan darah jika jenis, durasi, frekuensi dan intensitas aktivitas yang dilakukan tepat. Suryani, Noviana, Libri (2020) menyatakan aktivitas fisik seperti jalan kaki pada orang dewasa dengan hipertensi diketahui mampu menurunkan tekanan darah sebanyak $2 \%$, namun penting dan lebih efektif jika intensitas aktivitas fisik ditingkatkan menjadi 30-45 menit/hari sebagai salah satu 
strategi dalam pengelolaan penyakit hipertensi. Didukung oleh penelitian Jamaludin, Karyadi, Munawarah (2020) menyatakan hasil bahwa terdapat pengaruh antara berjalan dengan tekanan darah sebelum dan sesudah melakukan aktivitas berjalan dengan penurunan tekanan darah sistolik 9,40 dan diastolik 5,93.

Aktivitas fisik yang dilakukan baik itu ringan, sedang maupun berat hal tersebut tergantung pada jenis, durasi, frekuensi, dan intensitas kegiatan yang dilakukan (Karim, Oniballa, Kallo, 2018). Frekuensi merupakan berapa jumlah jenis olahraga atau aktivitas yang dilakukan oleh responden dalam seminggu (Abdurachim, Hariyawati, Suryani, 2017). Aktivitas fisik diketahui dapat membantu menurunkan tekanan darah jika aktivitas fisik tersebut dilakukan secara teratur dikarenakan aktivitas fisik teratur dapat membantu jantung untuk meningkatkan efisiensinya secara keseluruhan (Suryani, Noviana, Libri, 2020). Selain aktivitas fisik yang teratur, Kasumawati, Holidah, Yunin (2020) menyatakan aktivitas rutin juga dapat membantu dalam penurunan tahanan perifer sehingga akan terjadinya penurunan pada tekanan darah.

Proporsi paling tinggi yang mengalami hipertensi pada penelitian ini yakni responden dengan rentang usia 45-59 tahun sebanyak $(71,1 \%)$. Usia sangat berkaitan erat dengan hipertensi. Usia merupakan salah satu faktor terjadinya hipertensi yang tidak dapat diubah. Menurut Brunner \& Suddarth (2013) hipertensi dapat terjadi dimulai pada usia produktif yakni pada usia awal 30 tahun serta pada usia awal 50 tahun dan dapat terjadi secara bertahap akan tetapi dapat menetap. Selain itu dari hasil penelitian ini dapat diketahui bahwa hipertensi tidak hanya bisa terjadi pada lansia, akan tetapi dapat juga terjadi pada usia produktif. Hal ini karena dipengaruhi oleh dampak globalisasi sehingga terjadinya perubahan pada gaya hidup yang dapat menjadi pemicu terjadinya hipertensi diantaranya aktivitas fisik (Lestari, Lelyana, 2010).

Dalam penelitian ini didapatkan hasil bahwa hampir seluruhnya responden berjenis kelamin perempuan yakni sebanyak (92,9\%). Hal ini dikarenakan jenis kelamin berkaitan erat dengan kejadian hipertensi. Menurut Brunner \& Suddarth (2013) bahwa perempuan lebih banyak terserang penyakit hipertensi dibandingkan dengan laki-laki. Didukung oleh Yuliana, Faridah, Novitasari, (2020) yang menyatakan bahwa pada perempuan yang rentang usia nya diatas 40 tahun sudah memasuki masa pre menopause sehingga dapat menyebabkan penurunan pada hormon ovarium diantaranya estrogen dan progesteron, karena hormon estrogen yang berguna untuk meningkatkan kadar kolestrol HDL menurun akibatnya terjadi pula penurunan kadar kolestrol HDL sedangkan kadar kolestrol HDL tinggi sangat diperlukan guna mencegah terjadinya proses aterosklorosis, karena adanya proses tersebut maka perempuan menjadi lebih rentan terhadap terjadinya peningkatan pada tekanan darah atau hipertensi.

\section{SIMPULAN DAN SARAN}

Berdasarkan penelitian yang telah dilakukan oleh peneliti mengenai Gambaran Aktivitas fisik pasien hipertensi di Wilayah Kerja Puskesmas Guntur Garut pada tahun 2020 maka dapat disimpulkan bahwa persentase aktivitas fisik lebih banyak yang termasuk ke dalam aktivitas fisik sedang sebanyak 62 responden $(62,6 \%)$. Responden yang termasuk ke dalam aktivitas fisik berat sebanyak 28 responden $(28,3 \%)$ dan sebagian kecil termasuk ke dalam aktivitas fisik ringan dengan presentase 9 responden $(9,1 \%)$.

Diharapkan penelitian ini dapat menjadi masukan atau suatu informasi bagi puskesmas pada pengelolaan hipertensi atau 
penatalaksanaan hipertensi dengan melakukan aktivitas fisik secara rutin dan teratur penting dalam membantu penurunan tekanan darah dan mencegah terjadinya komplikasi pada hipertensi. Dengan demikian diharapkan hasil penelitian ini dapat membantu perawat untuk melakukan kajian aktivitas fisik secara menyeluruh guna meningkatkan pelayanan asuhan keperawatan dalam bentuk intervensi pada pasien hipertensi.

\section{DAFTAR PUSTAKA}

Afiah, W., Yusran, S., \& Sety, La Ode Muhamad. (2018). Faktor Risiko Antara Aktivitas Fisik, Obesitas Dan Stres Dengan Kejadian Penyakit Hipertensi Pada Umur 45-55 Tahun Di Wilayah Kerja Puskesmas Soropia Kabupaten Konawe Tahun 2018. Jurnal Ilmiah Mahasiswa Kesehatan Masyarakat, 3(2), 1-10.

Abdurrachim, R., Hariyawati, I., \& Suryani, N. (2017). Hubungan asupan natrium, frekuensi dan durasi aktivitas fisik terhadap tekanan darah lansia di panti sosial Tresna Werdha Budi Sejahtera dan Bina Laras Budi Luhur Kota BanjarBaru, Kalimantan Selatan, Gizi Indonesia, 39(1).37-48

Alves, A. J., Viana, J. L., Cavalcante, S. L., Oliveira, N. L., Duarte, J. A., Mota, J., ... Ribeiro, F. (2016). Physical Activity In Primary And Secondary Prevention Of Cardiovascular Disease: Overview Updatedphysical Activity In Primary And Secondary Prevention Of Cardiovascular Disease: Overview Updated. World Journal Of Cardiology, $8(10), \quad 575 . \quad H t t p s: / / D o i . O r g / 10.4330 /$ Wjc.V8.I10.575

Andriyati, R. D., \& Hendarsih, S. (2011). Studi Komparasi Tekanan Darah Dan Denyut Nadi Pada Orang Lanjut Usia Yang Mengikuti Senam Di Posyandu Jambu
Daerah Bantul (Doctoral Dissertation, Stikes'aisyiyah Yogyakarta).

Arikunto, S. (2009). Prosedur Penelitian: Suatu Pendekatan Praktik. Jakarta: Rineka Cipta.

Arlianti, Muhaimin, T., \& Anwar, S. (2019). Pengaruh Aktivitas Olah Raga Dan Perilaku Merokok Terhadap Hipertensi Pada Lansia Di Puskesmas Tomini Kecamatan Tomini Kabupaten Parigi Moutong Tahun 2019. 4.

Aryzki, S., \& Alfian, R. (2016). Brief Counseling Effect On Physical Activity Of Hypertensive Patients In Hospital Dr. H. Moch Ansari Saleh Banjarmasin, Indonesia. Jurnal Sains Farmasi Dan Klinis, 3(1), 84-90. Https://Doi. Org/10.25077/Jsfk.3.1.84-90.2016

Aryzki, S., Ayuchecaria, N., \& Sari, A. Khumaira. (2019). Pengaruh Brief Counseling Farmasis Terhadap Aktivitas Fisik Dan Hasil Terapi Pasien Hipertensi Rawat Jalan Di Poliklinik Penyakit Dalam Rsud Ulin Banjarmasin. Pengaruh Brief Counseling Farmasis Terhadap Aktivitas Fisik Dan Hasil Terapi Pasien Hipertensi Rawat Jalan Di Poliklinik Penyakit Dalam Rsud Ulin Banjarmasin, 5(1), 30-37.

Asriani, A., Bahar, B., \& Kadrianti, E. (2014). Hubungan Hipertensi Dengan Kejadian Gagal Ginjal Di Rumah Sakit Ibnu Sina Makassar Periode Januari 2011-Desember 2012. Jurnal Ilmiah Kesehatan Diagnosis, 4(2), 163-168.

Atun, L., Siswati, T., \& Kurdanti, W. (2014). Asupan sumber natrium, rasio kalium natrium, aktivitas fisik, dan tekanan darah pasien hipertensi. Indonesian Journal of Micronutrition, 6(1), 150177.

Bangala, C., Langelo, W., \& Sumenge, D. (2017). Hubungan Gaya Hidup Dengan 
Kejadian Hipertensi Pada Usia Dewasa Muda Di Wilayah Kerja Puskesmas Tateli Kecamatan Mandolang Kabupaten Minahasa (Doctoral dissertation, Universitas Katolik De La Salle).

Brunner, Suddarth. 2001. Buku Ajar Keperawatan

Medikal Bedah Edisi 8. Jakarta: Buku Kedokteran EGC.

Brunner \&Suddarth. (2013). Buku Ajar Keperawatan Medikal Bedah Edisi 8volume 2 (Jakarta: EGC)

Booth, M. (2000).Assessment of physical activity: an international perspective. Research quarterly for exercise and sport, 71(sup2), 114-120.

Cahyono, A. D. (2017). Hubungan Pengetahuan Tentang Hipertensi Dengan Sikap Perawatan Hipertensi Pada Pasien Hipertensi. Jurnal AKP, 6(1).

Committee, I. R. (2005). Guidelines For Data Processing And Analysis Of The International Physical Activity Questionnaire (IPAQ)-Short And Long Forms. Http://Www. Ipaq. Ki. Se/ Scoring. Pdf.

Craig, C. L., Marshall, A. L., Sjöström, M., Bauman, A. E., Booth, M. L., Ainsworth, B. E., ... \& Oja, P. (2003). International physical activity questionnaire: 12-country reliability and validity. Medicine \& science in sports \& exercise, 35(8), 1381-1395.

Dalimartha, S. (2008). Care Your Self Hipertensi. Care Your Self Hipertensi.

Damayantie, N., Heryani, E., \& Muazir. (2018). Faktor-Faktor Yang Mempengaruhi Perilaku Penatalaksanaan Hipertensi Oleh Penderita Di Wilayah Kerja Puskesmas Sekernan Ilir Kabupaten Muaro Jambi Tahun 2018. Jurnal AKP, 06, 224-232. Https://Doi.Org/10.26699/Jnk.V5i3. ART.P224
Dinkes Kabupaten Garut. (2017). Profil Kesehatan Kabupaten Garut. Seksi pengamatan penyakit Dinkes Kabupaten Garut. Garut

Dewi, M. I., Noviardhi, A., Prihatin, S., Tursilowati, S., \& Rahmawati, Y. A. (2018). Pengaruh Pemberian Kegiatan Olahraga Aerobik Terhadap Penurunan Tekanan Darah Pada Remaja Penderita Hipertensi Di Sman 10 Semarang. 39-45.

Elmiani, Sewang, N., \& Darmawan, S. (2014). Faktor Yang Berhubungan Dengan Kepatuhan Dalam Menjalankan Diet Pada Penderita Hipertensi Di Wilayah Kerja Puskesmas Larompong Kabupaten Luwu. Jurnal Ilmiah Kesehatan Diagnosi, 4(2), 213-220.

Fletcher, G. F., Landolfo, C., Niebauer, J., Ozemek, C., Arena, R., \& Lavie, C. J. (2018). Promoting Physical Activity And Exercise: JACC Health Promotion Series. Journal of The American College of Cardiology, 72(14), 1622-1639. Https:// Doi.Org/10.1016/J.Jacc.2018.08.2141

Febri Herdianto, B. A. Y.U. (2014). Pengetahuan Penderita Hipertensi Tentang Aktivitas Fisik Pada Hipertensi Di Puskesmas Ponogoro Utara (Doctoral dissertation, Universitas Muhammadiyah Ponorogo).

Gusnilawati, \& Buston, E. (2016). Hubungan Aktivitas Fisik Dan Kuantitas Tidur Dengan Kejadian Hipertensi.

Haris, P. (2017). Hubungan Tingkat Pengetahuan Terhadap Kepatuhan Kontrol Pada Lansia Dengan Hipertensi Di Puskesmas Lubuk Buaya Padang. Universitas Andalas.

Hardati, A. T., \& Ahmad, R. A. (2017). Aktivitas fisik dan kejadian hipertensi pada pekerja: analisis data Riskesdas 2013. Berita Kedokteran Masyarakat, 33(10), 467474.

Hasanudin, Ardiyani, Vita Mariyah, \& 
Perwitraningtyas, P. (2018). Hubungan Aktivitas Fisik Dengan Tekanan Darah Pada Masyarakat Penderita Hipertensi Di Wilayah Tlogosuryo Kelurahan Tlogomas Kecamatan Lowokwaru Kota Malang. Nursing News : Jurnal Ilmiah Keperawatan, 3.

Hidayat, W. (2011). Efektivitas Pemberian Tambahan Terapi Non Farmakologis untuk Mencegah Kenaikan Tekanan Darah pada Penderita Hipertensi Stadium I (Studi di Wilayah Kerja Puskesmas Baturetno I Kabupaten Wonogiri Tahun 2010) (Doctoral dissertation, Universitas Negeri Semarang).

Indonesia, S. (2004). Statistik Kesehatan 2004. Statistics Indonesia.

Indrawati, L. (2018). Pengaruh Senam Aerobik Terhadap Penurunan Tekanan Darah Pada Penderita Hipertensi. Citra Delima: Jurnal Ilmiah STIKES Citra Delima Bangka Belitung, 2(1), 31-38.

Infodatin, B. (2018). Pusat Data dan Informasi Kementrian Kesehatan RI,“. Indokator dan Target”, Jakarta.

IIP, J. S. S. Gambaran Gaya Hidup Pasien Hipertensi Di Poliklinik Jantung Rsau Dr. M. Salamun Bandung.

Idaiani, S., \& Wahyuni, H. S. (2017). Hubungan Gangguan Mental Emosional Dengan Hipertensi Pada Penduduk Indonesia. Media Penelitian Dan Pengembangan Kesehatan, 26(3), 137-144. Https://Doi. Org/10.22435/Mpk.V26i3.4245.137-144

Jabar, D. K. (2017). Profil Kesehatan Provinsi Jawa Barat 2016. 日本畜産学会報

Jatiningsih, K., Sudaryanto, A., Faizah Betty, R., \& Kep, A. S. (2016). Pengaruh Senam Lansia Terhadap Tekanan Darah Pada Lanjut Usia Dengan Hipertensi Di Posyandu Lanjut Usia Di Desa Wotgaleh Sukoharjo. Universitas Muhammadiyah
Surakarta.

Jamaludin, J., Karyadi, K., \& Munawarah, S. (2020, August). Pengaruh Jalan santai terhadap tekanan darah pada penderita hipertensi warga rw 005 pisangan barat ciputtat. in proceeding Seminar Nasional Keperawatan (Vol. 6, No. 1, pp. 165170).

JNC VII, 2007. The Sevent report of the Joint National Commite on prevention detection. Evaluation, and treatment of high blood pressure: Hypertension 42:1206-52, http//:hyperahajournals. org/content/42/6/1206.

Karim, N. A., Onibala, F., \& Kallo, V. (2018). Hubungan Aktivitas Fisik Dengan Derajat Hipertensi Pada Pasien Rawat Jalan Di Wilayah Kerja Puskesmas Tagulandang Kabupaten Sitaro. Jurnal Keperawatan. 6(1).

Kasumawati, F., Holidah, H., \& A'yunin, Q. (2020). Analisis Hubungan Kebiasaan Merokok dan Aktifitas Fisik dengan Kejadian Hipertensi Pada Kelompok Usia 45-54 Tahun. Jurnal Edu Masda , 4 (1), 11-20.

Kementrian Kesehatan RI. (2018). Hipertensi Membunuh Diam-Diam, Ketahui Tekanan Darah Anda. Kementerian Kesehatan RI. Sekretariat R Jenderal. Rencana Strategis Kementerian Kesehatan Tahun Rencana Strategis Kementerian Kesehatan Tahun. Https://Doi.Org/351.077 Ind R

Lestari, D., \& Lelyana, R. (2010). Hubungan Asupan Kalium, Kalsium, Magnesium, dan Natrium, Indeks Massa Tubuh, serta Aktifitas Fisik dengan Kejadian Hipertensi pada Wanita Usia 30-40 Tahun (Doctoral dissertation, Program Studi Ilmu Gizi).

LeMone, P., Burke, K. M., Luxford, Y., Raymond, D., Dwyer, T., Levett-Jones, T., ... \& 
Hales, M. (2011). Medical-surgical nursing: Critical thinking in client care. Pearson Australia.

Martienz-Rueda, A. J., Olivas-Martienz, A., Vega-Vega, O., Fonseca-Correa, J. I., \& Correa-Rotter, R. (2019). New 2017 American College of Cardiology/ American Heart Association High Blood Pressure Guideline:Healthcare Impact in Mexico and Other Developing Countries. Hypertension, 73(1), 142-147.

Mahmudah, S., Maryusman, T., Arini, F. A., \& Malkan, I. (2015). Hubungan Gaya Hidup Dan Pola Makan Dengan Kejadian Hipertensi Pada Lansia Di Kelurahan Sawangan Baru Kota Depok Tahun 2015. Biomedika, 7(2), 43-51. Https://Doi. Org/10.23917/Biomedika.V7i2.1899

Manurung, W. P., \& Wibowo, A. (2016). Pengaruh Konsumsi Semangka (Citrullus vulgaris) untuk Menurunkan Tekanan Darah pada Penderita Hipertensi. Jurnal Majority, 5(5), 102-107.

Manuntung, A.-. (2018). Hubungan Keyakinan

Diri Dan Aktivitas Perawatan Mandiri Pasien Hipertensi Di Wilayah Kerja Puskesmas Pahandut Kota Palangka Raya. Jurnal Ilmu Kesehatan, 7(1), 199. Https://Doi.Org/10.32831/Jik.V7i1.181

Mentari, S. (2017). Hubungan Hipertensi Dengan Penyakit Jantung Koroner Pada Pasien Rawat Inap Di Rsud Dr. M. Yunus Bengkulu (Doctoral Dissertation, Universitas Bengkulu).

Muhadi. (2016). JNC 8: Evidence-Based Guideline Penanganan Pasien Hipertensi Dewasa. Cermin Dunia Kedokteran, 43(1), 54-59.

Mukti, B. (2020). Penerapan DASH (Dietary Approach to Stop Hypertension) pada penderita Hipertensi.

Mordiana, P. R., \& Weta, I. W. (2014). Gambaran
Perilaku Pasien Hipertensi Di Wilayah Kerja Puskesmas Banjarangkan Ii Kabupaten Klungkung Bali 2014. ISM.

National Institutes of Health, National heart, lung, and Blood institute. The Seventh report of the joint national commite on prevention, detection, evaluation, and treatment of high blood pressure (JNC VIII). 2003 [Diakses tanggal 5 April 2016]. Https:/nhlbi.nih.gov.

Nastiti, W. N. (2017). Hubungan Aktivitas Fisik, Merokok, Dan Riwayat Penyakit Dasar Dengan Kejadian Hipertensi Pada Kelompok Usia 20-44 Tahun (Studi Di Wilayah Kerja Puskesmas Jelbuk Kabupaten Jember).

Nisa, H., \& Amran, Y. (2015). Hubungan aktivitas fisik dan kejadian penyakit jantung koroner di indonesia: analisis data riskesdas tahun 2013

Nor'alia, Lestari Ririn, D., \& Rachmawatii, K. (2017). Hubungan Gaya Hidup Dengan Kejadian Hipertensi Pada Usia Dewasa Di Desa Sapala Kecamatan Paminggir Kabupaten Hulu Sungai Utara. Dentino Jurnal Kedokteran Gigi, Ii(1), 68-71.

Notoatmodjo, S. (2012). Metodologi Penelitian Keshatan. Jakarta: Rineka Cipta

Nugroho, I. S. P., \& Muniroh, L. (2018). Hubungan Konsumsi Pangan Sumber Kalsium Dan Aktivitas Fisik Dengan Kepadatan Tulang Lacto Ovo Vegetarian Di Yayasan Buddha Tzu Chi Surabaya. Media Gizi Indonesia, 12(1), 64. Https:// Doi.Org/10.20473/Mgi.V12i1.64-71

Nurmalita, V., Annisaa, E., \& Pramono, D. (2019). Hubungan Kepatuhan Minum Obat Antihipertensi Terhadap Kualitas Hidup Pada Pasien Hipertensi. Faculty Of Medicine.

Pangestu, A. A. (2016). Efektivitas Rebusan Buah Pepaya Mengkal Dan Buah Mahkota 
Dewa Terhadap Perubahan Tekanan Darah Tinggi Pada Hipertensi Di Wilayah Kerja Puskesmas Kedungbanteng. Universitas Muhammadiyah Purwokerto.

Pratiwi, M. D. (2019). Penerapanterapi Progressive Muscle Relaxation Terhadap Tingkat Kecemasan Pada Pasien Hipertensi.

Pranandari, R., \& Supadmi, W. (2015). Faktor risiko gagal ginjal kronik di unit hemodialisis RSUD Wates Kulon Progo. 11(2), 316-320.

Platini, H., Pebrianti, S., \& Maulana, I. (2019). Tera Gymnastic Effective for Patient with Hypertension. Jurnal Keperawatan Padjadjaran, 7(3).

Pikir, B. S, dkk. (2015). Hipertensi Manajemen Komprehenshif. Mulyorejo Surabaya: Airlangga University Press (AUP).

Prof. Dr. Sugiyono. (2010). Metode Penelitian Bisnis. Bandung : Alfabeta.

Putri, S. M., Wahyu W, T., \& Suryani, Desri. (2017). Faktor Dominan Pada Tekanan Darah Penderita Hipertensi. Jurnal Media Kesehatan, 10(1), 031-040. Https://Doi. Org/10.33088/Jmk.V10i1.321

Putritsani, R., \& KUSUMA, H. (2018). Gambaran Aktivitas Fisik Pada Penderita Hipertensi Di Wilayah Kerja Puskesmas Kedungmundu Kota Semarang. Faculty Of Medicine.

Physical Activity Guidelines. (2017). Health Council of the Netherlands, 10.

Riskesdas. (2018). Hasil Utama Riset Kesehatan

Dasar Tahun 2018. Kementrian Kesehatan Republik Indonesia. Https:// Doi.Org/1 Desember 2013

Riskawati, Y. K., Prabowo, E. D., \& AI Rasyid, H. (2018). Tingkat Aktivitas Fisik mahasiswa program studi Pendidikan Dokter Tahun Kedua, Ketiga, Keempat. Majalah Kesehatan FKUB, 5(1), 27-32.
Runtukahu, R. F., Rompas, S., \& Pondaag, L. (2015). Analisis Faktor-Faktor Yang Berhubungan Dengan Kepatuhan Melaksanakan Diet Pada Penderita Hipertensi Di Wilayah Kerja Puskesmas Wolaang Kecamatan Langowan Timur. Analisis Faktor-Faktor Yang Berhubungan Dengan Kepatuhan Melaksanakan Diet Pada Penderita Hipertensi Di Wilayah Kerja Puskesmas Wolaang Kecamatan Langowan Timur, 3. Santi, Y., Aini, F., \& Liyanovitasari, L.(2020). Riwayat konsumsi mie instan dengan kejadian hipertensi di prolanis kecamatan ungaran barat (Doctoral dissertation, Universitas Ngudi Walyo).

Septiawan, T., Permana, I., \& Yuniarti, F. A. (2018). Pengaruh Latihan Slow Deep Breathing Terhadap Nilai Tekanan Darah Pada Pasien Hipertensi The Effect Of Slow Deep Breathing Exercise On Blood Pressure Value In Patient With Hypertension. Jurnal Ilmu Keperawatan, 111-118.

Setyowati, R., \& Wahyuni, S. (2019). Pengaruh Pendidikan Kesehatan Tentang Manajemen Hipertensi Terhadap Kejadian Berulang Peningkatan Tekanan Darah Pada Penderita Hipertensi Di Wilayah Kerja Dinas Kesehatan Kabupaten Majalengka Tahun 2019. Viii(16), 1-10.

Siti Fatonah, Tori Rihiantoro, T. A. (2017). Pengaruh Terapi Bekam Terhadap Darah Penderita Hipertensi. XI(1), 56-62.

Sumartini, N. Putu, Zulkifli, \& Adhitya Prasetya, A. Made. (2019). Pengaruh Senam Hipertensi Lansia Terhadap Tekanan Darah Lansia Dengan Hipertensi Di Wilayah Kerja Puskesmas Cakranegara Kelurahan Turida Tahun 2019 Ni. 1(2), 47-55.

Suryani, N., Noviana, N., \& Libri, O. (2020). 
Hubungan Status Gizi, Aktivitas Fisik, Konsumsi Buah dan sayur dengan kejadian hipertensi di Poliklinik Penyakit dalam RSD idaman Kota BanjarBaru. Jurnal Kesehatan Indonesia, 10(2), 100107.

Sugiyono. (2014). Metode Penelitian Pendidikan Pendekatan Kuantitatif, Kualitatif, Dan R\&D. Bandung: Alfabeta

Suyasmini, N. M., \& Maemonah, S. (2016). Kepatuhan Diet Menurunkan Frekuensi Kekambuhan Pasien Hipertensi Di Ppoliklinik Jantung Rsup Sanglah Denpasar. Jurnal Keperawatan, 9(1), 7-12.

Turege, J. N., Kinasih, A., \& Dyah K, M. (2019). Hubungan Antara Aktivitas Fisik Dengan Obesitas Di Puskesmas Tegalrejo, Kota Salatiga. Jurnal Ilmu Keperawatan Dan Kebidanan, 10(1), 256-263.

Trisnawati, N., Pebriyani, U., \& Gemilang, I. (2016). Hubungan Hipertensi Dengan Kejadian Penyakit Gaga L Jantung Kongestif Di R Umah Sakit Pertamina Bintang Amin Pr Ovinsi Lampung. Jurnal Ilmu Kedokteran dan Kesehatan, 3(4).

Utami, H. M. K. (2007). Hubungan Antara Kesegaran Jasmani Dengan Tekanan Darah Pada Karangtaruna Tunas Harapan Usia 20-39 Tahun Di Bulakrejo Sragen. Fakultas Kesehatan Masyarkat, Universitas Negeri Semarang, Semarang. Vestabilivy, E., \& Rukayah, S. (2014). Hubungan
Perilaku Pencegahan Komplikasi Dengan Kualitas Hidup Dan Stabilitas Tekanan Darah Pada Pasien Hipertensi Di Puskesmas Kecamatan Pondok Gede, Bekasi Tahun 2013. Jurnal Persada Husada Indonesia, 1(2), 1-9.

World Health Organization. (2008). Preventing Noncommunicable Diseases In The Workplace Through Diet And Physical Activity. Geneva: World Health Organization. Https://Doi.Org/ISBN 978 9241596329

World Health Organization. (2013). A Global Brief On Hypertension - World Health Day 2013. In World Health Organization. Https://Doi.Org/10.1136/ Bmj.1.4815.882-A

World Health Organization. Global recommendations on physical activity for health. Geneva: WHO; 2010 [cited 2017 Feb 4].

Yulanda, G., Lisiswanti, R., Kedokteran, F., \& Lampung, U. (2017). Penatalaksanaan Hipertensi Primer Treatment Of Primary Hypertension. 6, 25-33.

Yusuf, A., Fathurrahman, F., \& Magdalena, M. (2015). Hubungan Gaya Hidup Dengan Hipertensi Pada Pengunjung Puskesmas Teluk Dalam Banjarmasin. Jurnal Skala Kesehatan, 6(1).

Yonata, A., \& Pratama, A. S. P. (2016). Hipertensi sebagai Faktor Pencetus Terjadinya Stroke. Jurnal Majority, 5(3), 17-21. 